\title{
Joy in J. A. Comenius's Conception Miriam Prokešová
}

DOI: $10.32725 /$ cetv.2021.036

\section{Abstract:}

When we talk about the life of John Amos Comenius, we rarely associate it with joy. On the contrary, we know him as a person who faced many very unhappy situations in his life. However, Comenius in his works often mentions joy in various forms (laetitia, gaudium, voluptas, hilaritas). It is obvious that he perceives it as a life attitude from which we can and should draw in our lives. It is not only the joy of education, but, above all, the joy of God that gives man much-needed hope in his sorrows and pains. In the following article, we will 'immerse ourselves' in Comenius's thoughts and words that describe his attitude to life. We will follow the footsteps of Comenius's work and search for his conception of joy, which is still necessary for our lives today. The article is based on the forthcoming headword Joy for the work called Encyclopaedia Comeniana. It required a thorough study of Comenius's work mainly in the DJAK edition (Dílo Jana Amose Komenského, Praha: Academia, 1969-) and searching for this term in Comenius's writings mainly in Czech and Latin. Due to the availability of texts in the Czech language, this work is not always quoted; other editions of Comenius's work are also used as referenced in the footnotes.

Key words: joy, cheerfulness, consolation, the threefold pleasure of the soul, the joy of education, the joy of God

... Have a proclaiming heart, quiet tongue...

Leave now, my dear and stand in your lot until your end: enjoying the pleasure to which I have brought you, with pleasure. ${ }^{1}$

We see the life of John Amos Comenius as a life full of pain and losses, as if he barely knew joy. He was orphaned very early, then taken from the family environment of his four sisters. Later, after studying, his happy Fulnek period with his first wife Magdalena and two children ended with him hiding and eventually the death of his wife and children. ${ }^{2}$ Comenius comments on this in

1 Jan Amos KOMENSKÝ, Labyrint světa a ráj srdce, Opera omnia, Dílo Jana Amose Komenského - Johannis Amos Comenii opera omnia, Praha: Academia, Vol. 3 (hereinafter referred to as DJAK 3), 1978, (pp. 265-412), here p. 395, Chapter LIII. Prepared for publication by Jaroslav Kolár.

2 It is assumed that the Fulnek period in J. A. Comenius's life was one of the happiest. We know that he left Fulnek in the second half of December 1621. Until the autumn of 1622, he was hiding in Moravia, possibly in Přerov. In the spring of 1622, his wife and children died. It is not known whether he ever met his second child, who probably died shortly after birth. Also, the gender of both Comenius 
his work $O$ sirobè $(1622,1624)$, saying that 'a man carries an almost dead soul in a living body.' In the same year of 1623 , a year after the death of his wife and children, he began to write the famous Labyrinth of the World and the Paradise of the Heart. And the words at the end of this work are almost overwhelming given his own life destiny (not mentioning the difficulties which he later encountered in life). He writes there the words quoted at the beginning of this article, referring to the fact that we are to stand in our lot, that is, in anything that meets us in life, with pleasure, with joy, not only for a while, but until the end of life. ${ }^{4}$ So let's stand in our lot and let's accept everything, and not only that, let's enjoy it, let's live with joy! Let us go through this world, on our pilgrimage of life. And despite all the misfortunes, pains, losses, tears, let us gladly accept not only the beautiful, happy, merry, but also everything from the other side of the life spectrum. Whatever meets us, let's rejoice.

This is said by a person who has experienced a lot of misfortune, pain, suffering both in his private and professional life. He experienced the pain of losing his parents at an age when he could already perceive this loss, the pain of losing his wife and children, the pain of persecution and the pain of losing his homeland. He also knew about the burning of his books in Fulnek before his leaving for exile. Thirty years later, he witnessed a fire in Leszno that destroyed his work. His second wife also died and he was left alone with his young children. Perhaps this is why he married again, to a woman thirty years younger. He was welcomed with open arms on his pilgrimage in many places, but many times he also left accompanied by misunderstanding. His life was always as if on a roller coaster, where worries and pain seemed to prevail. At the end of the introductory dedication of his work Via lucis $(1641-1642,1668)$, he probably writes about it with a certain sigh: 'Comenius senex, cujus vita defecit in doloribus et anni in gemitibus.'

What was the joy for Comenius himself? The joy he mentions even at a time when, in his own words, he carried a soul that was almost dead in his living body? How did he perceive it in his works, how did he comment on it over the years in his writings? The notion of joy goes through Comenius's writings almost like a red thread. We find it under various terms, most often in Latin laetitia, gaudium, voluptas, hilaritas, and many more.

Firstly, let us think about how we can characterise joy in general.

\section{The Concept of Joy}

Joy is a person's mental state in which one experiences a feeling of pleasure and feels happiness. In other words, joy contains more than the currently used term well-being - a subjective feeling of contentment. Joy is not a static concept, as it has a number of degrees. It can be experienced either at the level of sensory satisfaction only (e.g., the joy of physical health, the joy of beautiful scenery of nature, or the joy of art, architecture, music, etc.). However, joy also has a mental and spiritual

children from this first marriage has not been historically documented.

3 Jan Amos KOMENSKÝ, O sirobě, Opera omnia, (DJAK 3), Praha: Academia, vol. 3, 1978, (pp. 427-472), here p. 434. It was prepared for publication by Milan Kopecký. The work was created during the year 1622 and published in 1624 for the first time. 'Indeed, when a man loses a good friend, it usually comes to his mind what he has had in him and what he has lost with him firstly. Desire, longing, feeling of pressure, weeping and lamenting, the eyes filled with tears and heart with blood, drying and thinning of the bones - that all come from that, and man carries a soul almost dead in his living body'

4 Jan Amos KOMENSKÝ, Labyrint světa a ráj srdce, Opera omnia, DJAK 3, Praha: Academia, vol. 3, 1978, (pp. 265-412), here p. 395, Chapter LIII. Prepared for publication by Jaroslav Kolár.

5 Jan Amos KOMENSKÝ, Via lucis, Opera omnia, Dílo Jana Amose Komenského - Johannis Amos Comenii opera omnia, Praha: Academia, vol. 14 (hereinafter referred to as DJAK 14), 1974, (pp. 279-385), here p. 292. Edited by Jarmila Borská, Julie Nováková. Czech translation by J. KOPECKÝ et al., Via lucis, Praha: SPN, 1961: [One of the humble men of desire, Old Comenius, whose life passed in pain and years in sorrow.] 
level. At these two levels, it can be understood as the driving force of life, associated with love as a principle of life, and as one of the basic preconditions of life.

Joy (as understood by the author of this article) is not seen only as a fleeting moment, a momentary flash lost in the past. It is not even a short-term fleeting emotion that comes from satisfying needs. Joy is not just a fleeting moment of happiness without long duration. On the contrary, joy is a lasting feeling of life, which is stored in the depths of our inner self and becomes a life attitude: staying on the top of things and of hardships. It becomes a shield that protects the aching soul and heart from despair and nothingness. Joy is a shield against anxiety and as such carries us through life.

\section{The Concept of Joy in Comenius}

If we are looking for an answer to the question of what made Comenius happy, let us take a look at his work.

In the book called $O$ sirobe (1624), he realises that there is nothing eternal in the world. Where there is joy, grief often comes as well. No pleasure is constant here in the world. Eventually, he sees the good for himself even in his parents' death. In the $10^{\text {th }}$ chapter, entitled $O$ ditkách osiřalých, he writes that '....more and more often the death of the parents brings good rather than bad for children...6 In the first chapter of this work he states that:

Everything that brings people in the world pleasure and they value it brings both joy and sorrow. Joy is brought when it is enjoyed, mourning comes when it leaves. As there is nothing eternal on earth. One thing goes after the other, they just pass. There is no lasting pleasure here, even though it lasts for a long time. ${ }^{7}$

John Amos Comenius combined joy with various states of man. The opposite of joy was fear, fear, horror, terror. However, he also associated joy with grief and pain, as we see in the above-cited work O sirobě. No pleasure in the world is constant, as he writes in the introduction to Centrum securitatis (1633):

The world is a spinning wheel,

It trembles sharply, makes noises and sounds.

He who does not sit in the centre,

Becomes tangled up and falls out. ${ }^{8}$

For Comenius, joy is a state that causes sensual merriment and pleasure, but not only that. Joy is also connected with will. Thus, it resonates with Comenius's concept of man as a whole, with his physical, mental and spiritual development. Joy is not perceived statically, but gradually. It culminates in the area of a spiritual level, in connection with God and with his work, wisdom, and love. The degree of the concept of joy was also reflected in Comenius's work in the way he expressed himself. He used certain Latin or Czech expressions which are variants or degrees of joy.

6 Jan Amos KOMENSKÝ, O sirobě, Opera omnia (DJAK 3), Praha: Academia, vol. 3, 1978, (pp. 427-468), here p. 449. Chapter X. O dítkách osiřalých: [... that the death of parents is more often for good than for evil to children; life, on the other hand, for harm more than for good.]

7 Jan Amos KOMENSKÝ, O sirobě, kap. I., Co a jak těžká věc jest siroba?, Opera omnia (DJAK 3), 1978, p. 433.

8 Jan Amos KOMENSKÝ, Centrum securitatis, to jest Hlubina bezpečnosti, Opera omnia, Dílo Jana Amose Komenského - Johannis Amos Comenii opera omnia, Praha: Academia, vol. 3, (hereinafter referred to as DJAK 3), 1978, (pp. 473-564), here p. 477. Translation of a footnote. Prepared for publication by Květa Neradová and Martin Steiner. 
Let us look at the key terms that Comenius defined or used for the term joy first. In this way, one can compare Comenius's basic textbook Janua linguarum reserata $(1631)^{9}$ and its Czech variant Dvére jazyků otevřené (1633). ${ }^{10}$ In both versions, we speak about chapters XXIX, $\$ 366$. In Latin, Comenius used the following words: hilaritas, laetitia, gaudium, voluptas (juncta tamen metui); and he used in verb form: laetari, gaudere, oblectare. In Dvére jazyků..., chap. XXIX, O vůli a náruživostech, he writes these words: '...Is he here? He exults in avidity, pleases himself, rejoices, amuses himself, enjoys himself, though loses his struggle; hence there is merriment, comfort, joy, delight, but it is all connected with fear.' ${ }^{\prime 1}$ In the Czech language, he uses the following expressions: veselost - merriment, utěšení (potěšení) - comfort (pleasure), radost - joy, větší radost - greater joy, rozkoš (spojená však s báznî) - delight (but connected with fear); and verbally: jásat chtivostí - exults in avidity, těšit se - please oneself, radovat se - rejoice, obveselovat se (kochat se) - amuse oneself.

In Pansofický slovník (Lexicon reale pansophicum), ${ }^{12}$ one finds these terms: laetitia, laetari, oblectare; gaudium, gaudere; hilaritas, jucunditas, voluptas; deliciae. ${ }^{13}$

Let us focus on a more detailed definition of these terms, as Comenius himself understood them.

- The term laetitia is the most general term for joy, joyful response to welcome, desired things that are good; laetari involved expressing joy, enjoying a good thing with joy. The related word oblectare means to bring joy by reminding one of a welcome, desired thing in the sense of being pleased, to please.

- The term gaudium is an expression of greater, deeper joy (laetitia profundior), when someone is full of joy, one's heart trembles with joy, one jumps (figuratively speaking), exults in joy, is filled with joy.

- Comenius calls externally manifested joy shown through the senses hilaritas. In other words, it is an expression of merriment (the definition is only for hilaris - it is joy manifested by the senses, movement of hands, body). Similarly, jucunditas is joy manifested by the senses.

- The term voluptas then refers to the reaction to pleasant things; it means the delight of 'being good' and being pleased with the highest good.

- The term deliciae then means delight, the ultimate delight.

From this small list we see that in Comenius's conception (and in both Latin and Czech) there is no joy as joy, that this word has different connotations and thus not exactly the same meaning in all forms.

\subsection{Joy as the Triple Delight of the Soul (Voluptas Animae) According to Comenius}

According to J. A. Comenius, joy can also be seen as joy emanating from the triple delight of the soul. How to approach this concept? We will try to do this in the following lines, based on the texts in Comenius's Didaktika and Velká didaktika. How does Comenius consider joy here?

9 Jan Amos KOMENSKÝ, Janua linguarum reserata, Opera omnia, Dílo Jana Amose Komenského - Johannis Amos Comenii opera omnia, Praha: Academia, 1986, (hereinafter referred to as DJAK 15/I), (pp. 269-301). Editors: Marie Kyralová, Martin Steiner.

10 Jan Amos KOMENSKÝ, Dvére jazyků odevřené, Opera omnia, Dílo Jana Amose Komenského - Johannis Amos Comenii opera omnia, Praha: Academia, vol. 11, (hereinafter referred to as DJAK 11), 1973, (pp. 359-435), here p. 387. Prepared for publication by Karel Hádek.

11 Jan Amos KOMENSKÝ, Dvére jazyků odevřené, Opera omnia, DJAK 11, 1973, Praha: Academia, p. 387.

12 According to Lenka Řezníková and Vladimír Urbánek, Comenius worked on this Pansophical Dictionary in the years $1662-1665$. In: Lenka ŘEZNÍKOVÁ and Vladimír URBÁNEK, Ex definitione. Pansofické pojmy J. A. Komenského a jejich dobové kontexty, Praha: Filosofia 2018.

13 Lexicon reale pansophicum. In: Vlasta Tatjana MIŠKOVSKÁ, Archiv pro bádání o životě a díle Jana Amose Komenského, Acta Comeniana, 1/1959, pp. 41-51. 
In chapter X of Czech Didaktika ${ }^{14}$ (1633) and its Latin version Didactica magna ${ }^{15}$ Comenius distinguished three degrees of joy, three degrees of delight (voluptas). He explained that delight does not mean any intemperance '... which foolish human stupidity calls delight. ${ }^{16}$ That spoils health, causes pain, illness and death. He understands it as the delight of the soul (voluptas animae), which is threefold, depending on its origin. 'The soul can have three kinds of delight, one in all things around; the second in oneself, the third in God.'17

Comenius explains the threefold origin of joy in the following way. Firstly, joy comes from things. One explores them and does some research, which brings pleasure and joy coming from the sharpening of reason (as evidenced by the biblical Book of Wisdom 8:16). Secondly, joy comes from ourselves when we observe how we understand the order of the world, the order of justice, when we see that the fulfillment of this order brings 'inner order' to us depending on how human virtues and good conscience develop. Thirdly, Comenius distinguishes the highest degree of delight, the ultimate joy. This joy comes from God, from the feeling that man obtains the grace of God and exults in his Father's favour and melts with love for God.

\subsection{The Joy (Delight) of Education in the Conception of Comenius}

The highest degree of voluptas animae (delight of the soul) is also associated with the joy of education, virtue, and piety, i.e., eruditio, virtus, pietas. Using other words, according to Comenius in Didaktika, these are: '... Three wells, from which all the springs of most perfect delights flow fully. ${ }^{18}$ These three wells - education, virtue, and piety, which bring man inner order, are to fulfill individuals and schools, all people, in everything that is essential for life. Later, in Pampaedia, in the fourth part of Obecná porada o nápravě věcí lidských (Consultatio de rerum humanarum emendatione catholica, 1644-1670), ${ }^{19}$ Comenius also called this delight deliciae, the light of the mind was hortus deliciarum (figuratively speaking, it was the light of pleasure), 'the garden of delight, the garden of joy'.

The fact that joy is connected with upbringing and education, and thus also with various requirements and principles, can be seen as early as in Comenius's Informatorium školy mateřské (1632). In this work, Comenius combines joy with love. Here, he advises parents to cheer children up by telling stories, singing, music: '... as a good mind is a key to health, and, according to Sirach's testimony, a happy heart is man's life; ... Parents should also make sure that their children have their merriment and pleasure. ${ }^{20}$ They should play with them, sing, show pictures, and support their own activities in every possible way, as it all strengthens the health of children. 'The more they know, the more they like it..21 In Škola dětství (Schola infantiae) ${ }^{22}$ in Pampaedia, Comenius uses the terms hilaris, laetitia, oblectatio and the hitherto unmentioned term placere (to please) and,

14 Jan Amos KOMENSKÝ, Didactica, Opera omnia, Dílo Jana Amose Komenského - Johannis Amos Comenii opera omnia, Praha: Academia, vol. 11 (hereinafter referred to as DJAK 11), 1973, (pp. 33-221), here pp. 74-75; 110-112. Prepared for publication by Stanislav Králík.

15 Jan Amos KOMENSKÝ, Didactica magna, Opera omnia, Dílo Jana Amose Komenského - Johannis Amos Comenii opera omnia, Praha: Academia, vol. 15/I (hereinafter only DJAK 15 / I), 1986, (pp. 29-209). Editors: Vojtěch Balík, Marie Kyralová, Stanislav Sousedík.

16 Jan Amos KOMENSKÝ, Didactica..., p. 74.

17 KOMENSKÝ, Didactica..., p. 74.

18 KOMENSKÝ, Didactica..., p. 74.

19 To know more about the issue of the origin, genesis, and fate of this work of Comenius, which remained unfinished, see the treatise Vojtěch BALÍK and Věra SCHIFFEROVÁ, Úvod k Obecné poradě, in: DJAK 19/I, 2014, Praha: Academia, pp. 21-34.

20 Jan Amos KOMENSKÝ, Informatorium školy mateřské, Opera omnia, Dílo Jana Amose Komenského - Johannis Amos Comenii opera omnia, Praha: Academia, vol. 11, (hereinafter referred to as DJAK 11), 1973, (pp. 223-275), here p. 243. Prepared for publication by Dagmar Čapková.

21 KOMENSKÝ, Informatorium..., p. 249

22 Jan Amos KOMENSKÝ, Vševýchova. Pampaedia, Praha: Státní nakladatelství, 1948, pp. 136-186. Chap. IX. Škola dětství. Klín mateřský, čili o prozíravé výchově lidského pokolení od narození až asi k šestému roku věku. Přeložil Josef Hendrich. 
again, he quotes the book of Sirach (Sir 30:23).

Cognition, education and thus growing wisdom should not only be the cause of inner order, but also the cause of pleasure and joy. Comenius writes of this in the preface to Theatrum universitatis rerum $(1616-1618,1627$ ?): 'The dweling place of wisdom is not bitter, and the living with wisdom is not painful, but pleasing and joyful.' ${ }^{23}$

The fact that he combines joy and pleasure with education and upbringing is evident from the already mentioned Didaktika (Didactica) and Obecná porada o nápravě věcí lidských. Education should be easy thanks to good, appropriate methods which leads to a culture of reason, will, emotion, abilitites, and use of life. In this way, people become wise and blissful (Didactica, Velká didaktika, Chapter XVII, Fundamentum II). Joy in connection with a good education can also be found in the work Gentis felicitas (Štěstí národa) (1654), ${ }^{24}$ where educational activity, wisdom, harmony, and peace for the whole nation bring 'joy' (laetitia). 'Felix ergo gens quae scholis bonis et libris bonis et circa juventutis educationem institutis aut consvetudinibus bonis abundat.'

How could the human mind become that garden of joy (delight) if properly educated? Comenius approaches this in his Pampaedia. In chapter III $^{25}$ he discusses the content of pansophical education leading to the completion of the essence of humanity. One of the requirements is: '... to make people rejoice over their gifts, being safe from disaster (evil) that way'. How Comenius imagined the method leading to this education, he explained, for example, in chapter VII, $\$ 26$ :

Human nature is adapted in such a way that the senses, reason, will, and all abilities are constantly looking for an adequate diet. If you deny it, they grieve, weaken, wither, die. If you add nutritions wisely, they will rejoice, be refreshed, come to life, and will cope with everything ... ${ }^{26}$ (In the Latin version, Comenius used the verbs gaudere and laetari).

\subsection{The Joy of God in Comenius's Conception}

Most often, however, John Amos Comenius connected joy with good, truth, freedom, unity, love. Comenius's metaphorical conception of light as several types of joyful enlightenment (physical, mental, and spiritual) was related to corrective activity, truth, love, and the hope of a universal correction of everyone-everything-throughout. This is evident in Obecná porada o nápravě věcí lidských, in the first two parts Panegersia and Panaugia. For example, in Panegersia, chapter IV, $\$$ 10 , there is the expression of delight of constant creation (in the Latin version, voluptas): 'Human activity does not consider it appropriate for itself to give up in advance. And so it immediately creates something else out of everything and does not end anything, because it is tempted by a kind of constant joy of creation ... ${ }^{27}$

23 Jan Amos KOMENSKÝ, Theatrum universitatis rerum, Opera omnia, Dílo Jana Amose Komenského - Johannis Amos Comenii opera omnia, Praha: Academia, vol. 1(hereinafter: DJAK 1), 1969, (pp. 95-181), here p. 104. Prepared for publication by Jiří Daňhelka, Karel Hádek, Antonín Škarka.

24 Jan Amos KOMENSKÝ, Gentis Felicitas, Opera omnia, Dílo Jana Amose Komenského - Johannis Amos Comenii opera omnia, Praha: Academia, vol. 13(hereinafter DJAK 13), 1972, (pp. 35-66), here p. 41. Prepared for publication by Julie Nováková, Martin Steiner. 'Happy is the nation that has plenty of good schools, good books, and good traditions and customs in the education of young people.' A Czech version is also in: Vybrané spisy Komenského, (VSK) VI., Praha: SPN, 1972, p. 261.

25 Jan Amos KOMENSKÝ, Vševýchova. Pampaedia, Chapter three. 'What does it mean that a person should be educated IN EVERYTHING, what completes the essence of humanity, why it is necessary and what is the possibility and ease of that thing', Praha: Státní nakladatelství, 1948, pp. 39-74. Translated by Josef Hendrich.

26 Jan Amos KOMENSKÝ, Vševýchova. Pampaedia, Chapter seven. Všeučitelství. To jest o universálních vzdělavatelích, učitelích vševědných, znalých učit všechny v̌̌emu v̌sestranně; jak veliká je jejich nutnost a jaké podmínky, Praha: Státní nakladatelství, 1948, pp. 102-131. Translated by Josef Hendrich.

27 Jan Amos KOMENSKÝ, Obecná porada o nápravě věcí lidských, in: Panegersia, Praha: Academia, 1992, p. 81. Translated by Jan Kalivoda, 
This is the motive for writing the work Obecná náprava. Comenius himself explains it:

Our intention is to show humanity, with God's grace, where all its good lies. We want to point out how we have crossed its boundaries and wandered in innumerable ways in vain. Finally, we want to indicate reliable, comfortable, and joyful paths to ancient simplicity, peace, and happiness. ${ }^{28}$

Comenius retains hope. It is evident, for example, in chapter VIII, $₫ 13$. Here he writes that 'all nature avoids pain and is pleased with love. So there is hope that when the reliable foundations of true unity (and therefore truth and peace) are discovered, everyone will jump with joy and willingly exchange mutual hatred for mutual love.' ${ }^{29}$

Also in Panaugia, Comenius connected joy (gaudere) with a desire to make things right. In Pansofia (Pansophia), Svět možný (Mundus possibilis), the importance of the light of the mind (hortus deliciarum) for understanding the things one encounters in the world is emphasised, and one should rejoice in it (gaudere).

Did you see the light of your mind in you? Did you know that no books have inserted it nor have I poured it into you? It is flowing into you from your mind. Do you feel joy? Rejoice, for you shall have an open spring within you. It will flow within you constantly without slackening. It will accompany you throughout your life... ${ }^{30}$

In Pansofia, Svèt materiální (Mundus materialis), in chapter VII (which deals with man, the user of the world around us) Comenius connected the perception of a beautiful, nice, necessary thing with good, a general love for that thing which includes pleasure (oblectatio) and desire, the effort to obtain it. If there are means, there is hope and joy (laetitia) and stimuli for further zeal. The attainment evokes a deeper joy (gaudium) coming from the fact that we have grasped it, delight (voluptas), spilling delight of the spirit (jucunditas animi). ${ }^{31}$

In Panorthosia, ${ }^{32}$ in the chapter on the correction of schools (chapter XXIV), Comenius combines the joy of education with the joy of God. Here he proposes a 'garden of delight' ('paradisus deliciarum') as part of the reform of secular administration. Chapter XXV mentions the joy (gaudium perfectum) of preparing people for the kingdom of heaven. This would be the task of a special university, to which a new philosophy, a new politics, and a new theology will contribute as part of the general reform.

However, Comenius's greatest and most frequently expressed joy was the joy of God, the joy of pious people, the joy associated with the hope of salvation. In Historie o těžkých protivenstvích, this joy is described in chapter LX. It is about 27 Czech martyrs, executed in 1621 in Prague by order of Emperor Ferdinand II: '... The sorrow of this hour will pass away and new, cordial, and eternal joy will come.'33

The joy associated with God, the giver of joy, often appears in Comenius's rewording of the Psalms called Žalmy (e.g., in IX, XIX, XX, XXI, XXVIII, XXXII, XXXV, XLI, XLIII). We can mention, for example, the conclusion of Psalm XXXII: 'Let all the godly ones rejoice in the LORD. Anyone

\footnotetext{
Martin Svatoš

8 KOMENSKÝ, Obecná porada..., p. 75.

9 KOMENSKÝ, Obecná porada..., p. 104

30 Jan Amos KOMENSKÝ, Obecná porada, In: Pansofia, translated by Martin Steiner, Jaromír Červenka, Markéta Klosová, 1992, p. 291.

KOMENSKÝ, Obecná porada..., p. 487.

Jan Amos KOMENSKÝ, Obecná porada, vol. III., 1992, in: Panorthosia, pp. 384, 413, 425, (pp. 253-462).

3 Jan Amos KOMENSKÝ, Historie o těžkých protivenstvích, Opera omnia, Dílo Jana Amose Komenského - Johannis Amos Comenii opera omnia, Praha: Academia, vol. 9 (hereinafter referred to as DJAK 9), 1989 (pp. 49-198), here p. 123. Prepared for publication by Amedeo Molnár, Věra Petráčková, Zuzana Pospíšilová and Noemi Rejchrtová.
} 
with a sincere ${ }^{34}$ heart, rejoice in the Lord. ${ }^{35}$ Or there is Psalm IX: 'O my righteous judge, you made the true judgment over me: joy, joy which is in you is brought by my heart to me.36

As early as in Premyšlování o dokonalosti křestanské (1622), ${ }^{37}$ the chosen soul piously meditates and cannot do anything else than weep with joy, as it would like to repay God with love for his good, especially for inner peace and joy in the spirit. Christian perfection includes love, tolerance, goodness, modesty, etc., and merriment and perfect comfort, joy in spirit, in heaven of delight. In the second part of Labyrint (that is, Ráj srdce), the inner light of pious Christians, the freedom of hearts devoted to God, love for God and neighbour brings joy, even delight, joy greater than the joy of the world; life is a joyous exulting in God, culminating in the delight of salvation. Similarly, in Svèt duchovní (Mundus spiritualis) in Pansofia, ${ }^{38}$ where the path to perfection needed for the reform of everything - in everything - throughout is described. For example, in chapter I, there is life in God as love and joy (amor et gaudium), or in chapter VII, joy (gaudium) of Christ the Redeemer is one of the seven stages of rebirth. In the final past of Pansofia, in chapter X, Jubileus jubileorum, ${ }^{39}$ the sign of the pinnacle of human wisdom is the lasting light of the mind, the lasting joyful heart (svavitates cordis perpetuae), the pinnacle of happiness (felicitatis culmen).

This - the praise of the Lord, a life consecrated in the joy of God and devoted to God, a lasting happy heart as the pinnacle of happiness - was the driving force of all of Comenius's action. He writes about this at the beginning of his professional and life career in the Theatrum universitatis rerum (1616-1618). Here, he also foreshadows his whole future life with words in which he addresses God in a somewhat unusual and strange way with youthful astonishment: '...wonderful God, my Lord. In your name I will begin with my work, do my work and finish it, and I will give myself and all my work to You, it will be under your protection... ${ }^{40}$ These words express the greatest impulse of Comenius's life, his activities, and his ability to rise again from his falls to peak activity. To the question of how Comenius overcame his pain and sorrow, his suffering, the almost dead soul that he carried (after all the wounds of his life) in his living body, we can answer using the words of the Old Testament. These are the words of Prophet Nehemiah, whom Comenius liked to quote: '...for the joy of the Lord is your strength' (Neh 8:10).

John Amos Comenius not only wrote about this power of joy, but he really felt and lived it in his life. It was his hortus deliciarum.

Pious people have joy in their hearts. ${ }^{41}$

Where there is God, there is heaven; where there is heaven, there is eternal joy: where there is eternal joy, there is one who does not know what more to ask for. The shadow is a joke, a laugh, every joy in the world is nothing against the joy of this... ${ }^{42}$

34 Jan Amos KOMENSKÝ, Žalmy, Opera omnia, Dílo Jana Amose Komenského - Johannis Amos Comenii opera omnia, Praha: Academia, vol. 4 (hereinafter referred to as DJAK 4), 1983, Žalmy (pp. 215-290), here p. 246. Upř́mé srdce - the original in DJAK. Prepared for publication by Milan Kopecký and Antonín Škarka.

37 Jan Amos KOMENSKÝ, Přemyšlování o dokonalosti křestanské, Opera omnia, Dílo Jana Amose Komenského - Johannis Amos Comenii opera omnia, Praha: Academia, 1978, vol. 3 (DJAK 3), especially Chapter III-XII and conclusion, pp. 185-233. Prepared for publication by Jarmila Koschinová, Stanislav Králík, Květa Neradová and Noemi Rejchrtová.

38 KOMENSKÝ, Obecná porada..., pp. 272, 336, 347.

39 KOMENSKÝ, Obecná porada..., pp. 490-491.

40 KOMENSKÝ, Theatrum..., p. 100.

41 KOMENSKÝ, Labyrint světa..., p. 390. This is the title of Chapter XLIX.

42 KOMENSKÝ, Labyrint světa..., p. 390. 
After all, in the already mentioned Labyrint světa a ráj srdce, Comenius speaks as follows:

Surely in the world there I have seen blindness and darkness, but I have seen this bright light as well; I have seen deception, but also truth; I have seen disorder, but also noble order itself; I have seen rush, but also peace; I have seen worries, but also joy; I have seen deficiency, but also abundance; I have seen slavery, but also freedom; I have seen difficulties, but also ease; I have seen tragic incidents, but also safeness... ${ }^{43}$

\section{Conclusion}

The concept of Comenius's joy is an unexplored area in the existing literature related to his work and life. At the same time, it is clear that this concept, and especially the concrete experience of that joy, was not completely foreign to him. Despite the hardships of life and the pain he experienced, he was a man of unrelenting faith, filled with the joy of God. This joy gave him a life force and enabled him to overcome all the hard and bad things which he encountered in life.

However, as can be seen from this article, Comenius's conception of joy does not apply to God himself only. Comenius himself perceives it from various possible angles considering the emotional states of man himself. It defines joy by expressions such as laetitia, gaudium, hilaritas, voluptas, deliciae, which differ from each other not only in possible expression, but also in the depth of experience. In his work (for example, in Dveře jazyki̊ odevřené, Pansofický slovnik, but even elsewhere), he defines the individual concept of joy. In Didaktika and in Didactica magna he understands joy as the triple delight of the soul - voluptas animae. It is then distinguished on the basis of its origin (source) as the joy of things (external), joy emanating from ourselves (that can be called inner joy, joy of the soul), and ultimate joy coming from God himself.

In Comenius's conception we also find the joy that relates to education, to knowledge as such. This joy is associated with virtue and piety (eruditio, virtus, pietas). These three bring us directly a garden of delight, a garden of joy, Comenius's hortus deliciarum. We see this not only in Obecná porada o nápravě věcí lidských, but also, for example, in Informatorium školy mateřské, in Theatrum univesitatis rerum, in didactics, in Gentis Felicitas, and elsewhere.

The ultimate joy for Comenius is the joy of God himself. In the sections of Obecná porada o nápravě vécí lidských, in Panegersia and Panaugia, this joy is the path to original simplicity, peace, and happiness. The joy of God is connected here with love as such; it helps to reach the light of the mind, the garden of delight, the already mentioned hortus deliciarum, and the delight of the spirit (jucunditas animi). The pinnacle of human wisdom is the permanent light of the mind, which is inextricably linked with the permanently happy heart (svavitates cordis perpetue).

With this constantly happy heart, we are to accept everything that we encounter in our lives. Using the words of Comenius from the beginning of this article: one should stand in one's lot until the end of one's life. In my article, I wanted to recall and bring this almost 'forgotten' but, at the same time, so important and inspiring message from the work and thinking of J. A. Comenius. 


\section{Contact}

Assoc. Prof. PaedDr. Miriam Prokešová, Ph.D.

University of Ostrava

Faculty of Education

Department of Education and Adult Education

Fráni Šrámka 1121/3, 70900 Ostrava - Mariánské Hory

Miriam.Prokesova@osu.cz 